\title{
Pragmatist Aesthetics by Richard Shusterman
}

A Bridge Between the Analytics and Continentals

\section{Paolo D'Angelo}

\section{(2) OpenEdition}

Electronic version

URL: http://journals.openedition.org/ejpap/789

DOI: $10.4000 /$ ejpap.789

ISSN: 2036-4091

\section{Publisher}

Associazione Pragma

Electronic reference

Paolo D'Angelo, "Pragmatist Aesthetics by Richard Shusterman », European Journal of Pragmatism and American Philosophy [Online], IV - 1 | 2012, Online since 23 July 2012, connection on 30 April 2019. URL : http://journals.openedition.org/ejpap/789; DOI : 10.4000/ejpap.789

This text was automatically generated on 30 April 2019.

\section{c) () $९$}

Author retains copyright and grants the European Journal of Pragmatism and American Philosophy right of first publication with the work simultaneously licensed under a Creative Commons AttributionNonCommercial-NoDerivatives 4.0 International License. 


\title{
Pragmatist Aesthetics by Richard Shusterman
}

\author{
A Bridge Between the Analytics and Continentals
}

\author{
Paolo D'Angelo
}

1 When the first edition of Pragmatist Aesthetics came out in 1992, it was immediately perceived as an important new step in Anglo-American philosophy. The aesthetics of the English language were clearly dominated by the analytic current, and the ties with the "continental" debate at that time were quite tenuous. Shusterman, however, reconnected with the pragmatic tradition, and in particular with the aesthetics of John Dewey, thus breaking with many consolidated schemes of thinking, which was immediately evident. Today, however, we can measure another significant effect of Shusterman's work. Now that the analytic and continental traditions, even in aesthetics, are no longer two entirely separate provinces, and they have begun to take cognizance of each other, it can be seen that Shusterman's pragmatist aesthetics also acted as a sort of channel of communication between these two traditions. This is a somewhat paradoxical effect, given that Shusterman belonged to neither school of thought, but this was made possible precisely because of this double extraneousness. Referring to pragmatism, Shusterman brought to light certain intrinsic limits of the analytic approach, and he did so based on a line of thought that although tied to its origins and its development in the New World, seemed closer to other modes of philosophy of the old Continent. In this paper we will deal with the relationship between Pragmatist Aesthetics and analytic aesthetics, and then and look at two questions which have already been mentioned, that is, the aesthetic experience and popular art..

2 In 1987 Shusterman edited a special issue of "The Journal of Aesthetics and Art Criticism" entitled Analytic Aesthetics: Retrospect and Prospect, ${ }^{1}$ which was anything but a simple informative recapitulation of the issue. In reconstructing the origins and development of analytic aesthetics, Shusterman brought to light some very salient limits. Beginning with a broad conception of analytic aesthetics, which included authors such as N. Goodman, R. Wollheim and A. Danto, and thus went far beyond the traditional images of analytic 
philosophy as a force for the clarification of language, Shusterman pointed out the difficulties which were at the heart of analytic aesthetics due to the claim of doing without any evaluation cultivating the myth of a purely classificatory analysis of a work of art; and he saw in the "neglect of the socially charged context of art" a negative heredity passed on from the formalistic critical orientation of analytic aesthetics, and noted how the latter paid very little attention to history. He was aware of the removal of natural beauty that the exclusive orientation of the work of art carried in itself. At the time Shusterman was writing, a growing uneasiness in analytic aesthetics was beginning to be felt towards the newer forms that were gaining critical acclaim. There was the advent of deconstructionism and cultural studies, with which the dialogue was becoming ever more difficult, and a questioning of a discipline that had always been thought of as a sort of "philosophy of criticism" in both the literary and artistic fields. In the publication in a single volume of the essays initially collected from the special issue of the Journal, Shusterman also added contributions from authors who were extraneous to the analytic tradition such as P. Bourdieu, Ch. Norris and Ch. Altieri, with the stated purpose of favoring a confrontation with the "Continental Theory."

With a background that included Adorno and Bourdieu, Shusterman is much more equipped to discuss the recent developments of literary and artistic criticism, and a book such as Pragmatist Aesthetics demonstrates this very well. In this volume, one of the central themes of the analytics in aesthetics debate, the definition of art, is brought to question. When Shusterman examines G. Dickie's Institutional Theory, Levinson's Historical Theory as well as the efforts of Danto to define art starting from "artworld" and "aboutness," he does not do it merely to demonstrate the difficulties in each of these attempts, but also to push the investigation further along. Shusterman asks if we really need a definition of art. Do we need a definition of art in order to appreciate a work of art? Here not only the pragmatist statement but also the sociology of art begins to bring forth their fruits, because they force Shusterman to distrust every abstract attempt of a definition and to keep in mind that art is a social practice rather than a formalized institution. With this as a basis, a true diatribe against the obsession for definition can be seen, which has conditioned analytic aesthetics for more than three decades. These pages of Pragmatist Aesthetics, written when the problem of the definition of art was still at the center of the analytic debate, today assume a very singular value and can even appear prophetic. From the beginning of the new century the same analytic philosophers have noticed with more clarity the innate limits of the search for the definition of art in terms of necessary and sufficient conditions. An early significant symptom, a search for "definition" in "narrative" terms proposed by N. Carrol, already existed in the 1990 s. Shusterman deemed this the best possible definition to be found within the framework of analytic theory, and it does not strictly speak of definition in terms of conditions, but it attempts to reconstruct the historical and traditional ties that permit the identification of certain practices as "artistic." Shusterman's doubts are confirmed by the return to the neo-Wittgensteinian skepticism with the essays by B. Gaut, Art as a Cluster Concept, ${ }^{3}$ by J. T. Dean The Nature of Concepts and the Definition of Art. ${ }^{4}$ The interventions on the theme, practically ubiquitous between 1970 and 1990 became rarer and more cautious and the position previously occupied by the problem of definition seemed to be taken over by other themes, such as the ontology of art or the debate over imagination.

Instead of the formal problem of the definition of art, Shusterman looked at a strong restatement of the notion of aesthetic experience. Even in this case he encountered deep 
rooted closure in the analytic field. If at the beginning of the analytic project the notion of aesthetic experience played an important role, as witnessed in Aesthetics: Problems in the Philosophy of Criticism by Monroe C. Beardsley, it later faced a series of criticisms which considered it in a destructive way. One needs only think of the categorical rejection of the aesthetic experience brought forth in G. Dickie's essay The Myth of Aesthetic Attitude ${ }^{5}$ which was followed by an attack to Beardsely in Beardsley's Phantom Aesthetic Experience and restated in Art and the Aesthetic. There are no characteristic features that differentiate the aesthetic experience from other experiences, and therefore the latter can be identified only if it comes first and independently defines what an aesthetic object is. The path does not go from the aesthetic experience to art, but on the contrary in the opposite direction, from a work of art to the aesthetic experience. ${ }^{6}$ Nor has criticism of the notion of aesthetic experience remained the prerogative of Dickie, whose attacks are known for their bluntness and oversimplification. Even a philosopher infinitely more capable of nuance, such as A. Danto, has made it one of the fundamental aces of his own theory. In fact, for Danto an aesthetic definition of a work of art (meaning a definition based on a particular type of experience that includes all of art) is threatened by circularity. Now, however, according to Danto in order to aesthetically appreciate the sensitive qualities of an object of art, we must already know that the object is a work of art, and this is not known by experiencing the object itself, but from the theory and history of art. ${ }^{7}$ In Danto's opinion this is confirmed by the fact that there exist works of art that do not at all present aesthetic requisites, meaning that they are totally without aesthetically measurable qualities or values. Therefore, between an object which is a work of art and one that is not, there can be differences that in no manner can be considered perceptive differences. Not all artistically relevant differences are of a perceptive nature. It is not, then, the aesthetic experience which allows us to decide what is or what is not a work of art, but rather an interpretive act which is based on theory and historic tradition. For Danto, interpretation must take the place that in traditional theory was occupied by aesthetic experience.

5 Shusterman knows the objections to the concept of aesthetic experience and its usability. His article The End of Aesthetic Experience in the "Journal of Aesthetics and Art Criticism" published in 1997 demonstrates it very well. The title plays with the ambiguity of the term "end." On one hand it wants to be "a reasoned account of the demise" of the notion of aesthetic experience, but on the other hand it tries to furnish "an argument for reconceiving and thus redeeming its purpose." ${ }^{8}$ Characteristic of Shusterman's procedure is the fact that he does not limit himself to giving an account of the criticism of the notion of aesthetic experience studied in the analytic field but also extends his investigation to continental philosophy, and thus doing, shows a surprising convergence of the two traditions. In the 20th century even great European philosophy rejected the aesthetic experience. It was criticized by Heidegger (remember, for example, the restrained attacks in Nachwort to Der Ursprung des Kunswerkes to the notion of Erlebnis, or in other words "the lived experience"), by Gadamer (for whom the aesthetic experience was strictly linked with the aesthetische Unterscheidung which both sterilized and made the contact with a work of art unproductive). It was also criticized by Adorno. The rejection of aesthetic pleasure, a pivotal point in Adorno's rigoristic theory, is in the first place a rejection of the aesthetic experience and of its gratifying and life-enhancing aspects.

6 There is also a tradition in continental aesthetics which safeguards the role of aesthetic experience; for example the phenomenological line (M. Dufrenne's Phénoménologie de 
l'expérience esthétique or Jauss' Rezeptionsaesthetik; not by chance was an active and positive role in aesthetic pleasure retrieved, in direct opposition to Adorno's position). Shusterman does not find anything that is analogous in the analytic tradition and turns to the pragmatic one, in particular to Dewey, in which the centrality of the notion of experience is found. Shusterman does not attempt to hide the difficulty that Dewey encounters when he tries to transform his concept of aesthetic experience into "a theoretical definition of art." However, there remains the fact that by insisting "on privileging dynamic aesthetic experience over the physical object that conventional dogma identifies and that fetishizes as art" the philosopher "frees art from object fetishism (and) also from its confinement to the traditional domain of fine art." 9

7 Shusterman emphasizes the fact that the rejection of aesthetic experience has created many more problems than it has resolved. In fact, this rejection has enclosed the aesthetic debate in a sterility of procedural theories, focusing solely on art, forgetting the existence of an aesthetic experience in and derived from nature and preventing the thematizing of the phenomenon of widespread anesthetization which is so characteristic of our times. To divide and oppose pleasure and meaning, sentiment and consciousness, enjoyment and understanding, as Danto and Adorno do for different reasons, means losing sight of the fact that what art does is literally hold together these pairs of presumed opposites. The criticisms of the aesthetic experience have shown that it furnishes neither sufficient nor necessary conditions for the application of our concept of art, but this does not mean that it does not constitute "a more general background condition for art." By conciliating the anaesthetization of aesthetics Dickie and Danto brought nothing good to it, because reflecting on the art itself, it closed it even more into itself in a self-referential and intellectualistic circuit far removed from popular taste. It is therefore worth recalling the notion of aesthetic experience, "not for a formal definition but for art's reorientation toward values and populations that could restore its vitality and sense of purpose." ${ }^{10}$

8 Perfectly consistent with the reclamation of aesthetic experience - where the influence exercised on Pragmatist Aesthetics by the Aesthetics of John Dewey is absolutely clear ${ }^{11}$ we find another qualifying aspect of Shusterman's aesthetics, the re-evaluation of popular art. Even in this case Shusterman does not receive immediate support from either the analytic tradition or from the continental one. The very terminology chosen by these two traditions to indicate this totally modern phenomenon of art directed to a vast portion of the population and which seems enjoyable, owing to the techniques of reproduction, for spectators from the most varied extractions and without any limits to time and place, are indicative of the attitude of depreciation and superiority. Adorno and Horkeimer, in a celebrated chapter of Dialektik der Aufklaerung, speak of Kulturelle Industrie, Industrial Culture, thus highlighting the commercial, and at the same time the stereotyped, character of this type of artistic production. Analytic aesthetics was late at facing these types of problems - the first contributions to these themes did not appear until the end of the 1980s - and although it did so by claiming that it wished to maintain a distance from an evaluative position, it often accepted the current expression of "mass art" without being able to free this art from the prejudices that accompanied it. This is evident, for example, in the work which is probably considered the most exhaustive on this theme, A Philosphy of Mass Art by N. Carroll. ${ }^{12}$ Shusterman on the other hand speaks of popular art, and, in the fourth chapter of his book, goes on to challenge, point by point, the current prejudices towards mass art: its negative social and political influence, its 
ephemeral nature, its superficiality, the lack of active involvement by its consumer, and its inability to truly rise to pure form. The arguments used by Shusterman to dismantle each one of these objections are very persuasive, but his criticism of current prejudices towards popular art is not carried out only on the level of theoretic analysis. The analytic approaches to the problem of mass art normally focus on the ontology of art and are above all interested in the ontological requisites that the artistic product must possess in order to have mass appeal (the possibility of mechanical reproduction, the fact of being a tokenof a type, a work of multiple instances, etc). However, Shusterman is primarily interested in the cultural and social implications of popular art. Even in this case, he reacts directly to the Dewey's legacy, if we consider the suspicion that Dewey nurtured toward art confined to museums and incapable of truly entering the life of the people.

Shusterman is thus moved by an authentic interest in the mass spread of art, an interest that comes from involvement and direct knowledge, that has none of the suspect and disparaging attitudes of "refined" intellectuals. And if a demonstration is needed, read the pages of the chapter dedicated to The Fine Art of Rap in Pragmatist Aesthetics or Affect and Authenticity in Country Musicals in Performing Live, a book published by Shusterman in $2000,{ }^{13}$ and in which the first part is entirely dedicated to Aesthetic Experience and Popular Art.

\section{NOTES}

1. R. Shusterman, (1987), "Analytic Aesthetics: Retrospect and Prospect," The Journal of Aesthetics and Art Criticism, (45) 2, 115-24.

2. R. Shusterman (ed), (1989), Analytic Aesthetics, Oxford-New York, Basil Blackwell. With respect to the edition stated there must also be noted the intervention of J. Margolis, another American aesthetics scholar where the pragmatic influence is very strong.

3. B. Gaut, (2000), Art as a Cluster Concept, in N. Carroll (ed.), Theories of Art Today, Madison, University of Wisconsin Press.

4. J. T. Dean, (2003), "The Nature of Concepts and the Definition of Art," The Journal of Aesthetics and Art Criticism, 2003 (61), 1, 29-35. Concerning the return, on the subject of the definition of art, to the "scepthic" position of the 1950s where the debate was lively, see D. A. Kaufman, (2007), "Family Resemblances, Relationalism, and the Meaning of 'Art'," British Journal of Aesthetics, (47) 2, 280-97.

5. G. Dickie, (1964), “The Myth of Aesthetic Attitude," American Philosophical Quarterly 1, 55-66.

6. G. Dickie, (1974), Art and the Aesthetic. An Institutional Analysis, Ithaca, Cornell University Press.

7. G. Dickie, Art and the Aesthetics, cit., 90 et seq.

8. R. Shusterman, (1997), "The End of Aesthetic Experience," The Journal of Aesthetics and Art Criticism, (55) 1, 29.

9. R. Shusterman, "The End of Aesthetic Experience," cit., 33.

10. R. Shusterman, "The End of Aesthetic Experience," cit; recently Shusterman stressed his 'rehabilitation' of the aesthetic experience in R. Shusterman, (2006), “Aesthetic Experience: from Analysis to Eros," The Journal of Aesthetic and Art Criticism 2, 217-29. 
11. For Shusterman's debt to Dewey's aesthetics see the chapter in Pragmatism. Dewey, written by Shusterman for D. B. Gaut \& D. Lopes eds., (2002), The Routledge Companion to Aesthetics, LondonNew York, Routledge, 121-32.

12. N. Carroll, (1998), A Philosophy of Mass Art, Oxford, Clarendon Press.

13. R. Shusterman, (2000), Performing Live, Ithaca and London, Cornell University Press.

AUTHOR

PAOLO D'ANGELO

Università Roma Tre

dangelo[at]uniroma3.it 